Thorax (1958), 13, 130.

\title{
EXTRAPERIOSTEAL PLOMBAGE IN THE TREATMENT OF PULMONARY TUBERCULOSIS
}

\author{
BY \\ F. H. YOUNG \\ From the Brompton Hospital, London
}

(RECEIVED FOR PUBLICATION FEBRUARY 24, 1958)

For a physician to review a surgical operation and its results may seem out of place, but in the treatment of a patient suffering from pulmonary tuberculosis any operative procedure is only an episode in what frequently is a long story. The physician knows, or should know, the patient's reaction both physical and immunological to the tubercle bacillus, and the patient's psychological approach to the disease, better than the surgeon. A seven-rib thoracoplasty for a chronic cavity was undertaken on a girl rather against my judgment with a brilliant result from the point of view of tuberculosis, but although there was no undue deformity the patient became an alcoholic, and finished up in a mental institution because of the shock of her appearance. This paper reviews my experiences in extraperiosteal apicolysis with plastic material space-filling (E.P. plombage) on patients submitted to my surgical colleagues for this operation. Most of the operations were performed by my surgical colleagues at the Brompton Hospital, N. R. Barrett, W. P. Cleland, and Oswald Tubbs, though one or two were performed by other surgeons. The material used was largely lucite balls, but in some cases N. R. Barrett used plastic sponge material. In one or two patients the second and third ribs were resected at the time of operation. The points discussed in this paper exclude the period which the patient spent in the operating theatre and the succeeding 14 days unless what happened affected the later result. The decision on the timing of the operation was left to me.

It is, I think, generally agreed that apart from cases with severe bronchial stenosis an artificial pneumothorax, entirely uncomplicated by adhesions, produces the optimum selective collapse and will lead to healing with smaller permanent loss of lung function than any other form of collapse therapy. The number of cases in which this is possible is limited; so for the last 30 years workers have striven to find a method by which a similar result can be obtained where pneumothorax is impossible. The modern thoracoplasty is a good therapeutic substitute but has considerable disadvantages. This has led to a search for a method by which removal of several ribs can be avoided.

Extrapleural pneumothorax was tried, using fat, muscle, and oil as substitutes for air, but all these failed; many good results were obtained from extrapleural pneumothorax when used judicially and when the whole proceeding was in the hands of one who understood it ; but, practically, many complications occurred. When non-irritant plastic materials became available these were substituted in various forms, notably lucite balls by Wilson in 1946, the polysen material in an envelope by Morriston Davies in 1948, and polysen sponge by Bing in 1950. Good immediate results were reported, and the method was used extensively in Japan and France. However, adverse reports soon appeared; these were due to space infections, both septic and tuberculous, which often led to fistulous communications between the space and the bronchial tree. The filling material had to be removed with much morbidity and some mortality. The extrapleural method had two fundamental failings: First, it did not allow sufficient thickness of insulating tissue between the filling $N$ material and the active tuberculous focus. Two, $N$ it endangered the maintenance of an adequate $N$ blood supply to the surface of the underlying lung; accordingly disasters were likely in theory and occurred in practice. The next step was the introduction of an extraperiosteal strip; in this when the space was produced the underlying lung + remained covered by a layer which included the $\frac{0}{0}$ periosteum of the ribs and the intercostal muscles ; $\stackrel{\mathbb{D}}{\mathbb{D}}$ the ribs were left bare - the so-called " bird cage " $\frac{\rho}{\mathbb{D}}$ operation. Objections to the extrapleural method $\varrho$ are obviated because a reasonably thick layer of healthy tissue intervenes between the plastic 8 material, and the main blood supply from the 
adherent pleura is maintained. The mediastinal strip, however, remained a potential menace.

About the time when this operation was introduced anti-tuberculous drugs became available, but at the start they were sparingly used. The use of the anti-tuberculous drugs before and after operation and their effect on results appears to have been treated rather casually by many writers ; this makes it impossible to make any comparison of the results published by various authors. Engberg and Hansen (1953) in Copenhagen, in a paper which discusses the subject in more detail than most, write: "Antibiotic treatment against tuberculosis if indicated is administered before the operation and continued upon usual lines." Cleland (1956) refers only casually to their use. Laird and Stephens (1953) do not mention antibiotics. The same applies to a series of articles on the subject from France reported in Le Poumon in March, 1954. Jackson and McCann (1956), however, state that all patients had full medical treatment with chemotherapy for from three to 18 months before operation. Their results are satisfactory. Out of 109 cases, $83 \%$ were satisfactory without and $91 \%$ with further treatment. MacArthur (1957) reporting the treatment of 22 space infections gives us no details of their drug treatment.

In the series quoted below the importance of adequate pre-operative anti-tuberculous drug treatment is clearly shown. I have taken three months as the minimum period of such treatment which can be deemed adequate. The drugs used have varied from case to case. It will be seen that many had no pre-operative treatment, but this was due to the series starting in 1949 when antituberculous drugs were not freely available. It is difficult to demonstrate the importance of postoperative drug treatment as, until fairly recently, the main indication for long continuance was the condition of the contralateral side.

\section{MATERIAL}

My material consists of 66 patients in whom 71 E.P. plombage operations were performed. The classification of age and sex incidence is contained in Table I. The categories are roughly those of the American Tuberculosis Association, except that three patients are classified as "advanced" having gross emphysema.

Table II shows the condition of the patient at the time of the E.P. plombage. There were 30 patients in whom the disease was advanced and in whom the other side was unstable, i.e., it had not been completely static during the previous six
TABLE I

MATERIAL (66 PATIENTS)

\begin{tabular}{|c|c|c|}
\hline \multicolumn{3}{|c|}{ Category } \\
\hline$\underset{50}{\text { Advanced }}$ & $\begin{array}{c}\text { Intermediate } \\
9\end{array}$ & $\underset{7}{\text { Early }}$ \\
\hline \multicolumn{3}{|c|}{ Age } \\
\hline Under 18 years & $\begin{array}{l}18-50 \text { years } \\
57\end{array}$ & Over 50 years \\
\hline \multicolumn{3}{|c|}{ Sex } \\
\hline Women under 30 & $\underset{16}{\text { Women over } 30}$ & Men \\
\hline
\end{tabular}

months, and in addition three had already had five rib thoracoplasties and three had pneumothoraces on the contralateral side. Of the 15 in whom disease of the contralateral side was stable, one had a cavity on this side, but it had shown no change for six months.

TABLE II

CONDITION OF PATIENTS AT TIME OF E.P. PLOMBAGE (66 PATIENTS)

\begin{tabular}{|c|c|c|c|c|c|c|}
\hline \multirow{2}{*}{ Category } & \multirow{2}{*}{$\begin{array}{l}\text { Uni- } \\
\text { lateral }\end{array}$} & \multirow{2}{*}{ A.P. } & \multirow{2}{*}{ Thoracic } & \multicolumn{2}{|c|}{ Bilateral } & \multirow{2}{*}{ Total } \\
\hline & & & & Stable & Unstable & \\
\hline $\begin{array}{l}\text { Early } \\
\text { Inter- } \\
\text { mediate } \\
\text { Advanced }\end{array}$ & $\begin{array}{l}7 \\
4 \\
3\end{array}$ & $\begin{array}{l}- \\
-\end{array}$ & - & $\begin{array}{r}- \\
4 \\
11\end{array}$ & $\begin{array}{r}- \\
1 \\
30\end{array}$ & $\begin{array}{r}7 \\
9 \\
50\end{array}$ \\
\hline Totals & 14 & 3 & 3 & 15 & 31 & 66 \\
\hline
\end{tabular}

Table III refers to the E.P. plombage side at the time of operation, together with the incidence of cavitation and a positive sputum. All had had a positive sputum at some time, and in 37 preoperative culture was positive. All the patients except one had had cavitation of the plombage side, and, in 50, cavitation existed at the time of operation.

TABLE III

CONDITION OF SIDE UNDERGOING E.P. PLOMBAGE (71 OPERATIONS)

\begin{tabular}{ll|c|c}
\hline & Cavitation & Positive Sputum \\
\hline At any time & $\cdots$ & 70 & 71 \\
At time of operation & $\cdots$ & 50 & 37 \\
\hline
\end{tabular}

In Table IV the progress of the patient is shown in detail. The follow-up is for a minimum of three years following the operation, with an average of five years. All the patients except two have been seen this year, nearly all personally, but in a few a radiograph, a sputum report, if sputum was present, and a report from the chest physician have been accepted. To be described as "satisfactory" the patient must have had a post- 
operative tomograph showing no cavitation, with a succession of negative sputa or gastric lavage cultures following operation. In some patients a positive sputum persisted for several months following the operation before becoming persistently negative. The two patients, lost sight of this year, were followed up for four years after the operation, and when last seen were "satisfactory" ; there is every reason to think that they have remained so.

It will be seen that, of the 65 patients, 54 are satisfactory without further operation, seven are satisfactory after further operation. Two have died of coronary thrombosis three years after operation; in both at necropsy the space was uninfected and the cavities closed. One patient has died of progressive pulmonary tuberculosis, and in this woman the plombage space was infected. In the patient classified as unsatisfactory an area in the apex of the lower lobe on the other side had recavitated. Among the 54 classified as satisfactory, three have a reduced pulmonary function, which makes them unfit for remunerative work, but they are perfectly fit to do their housework at home.

TABLE IV

PRESENT CONDITION OF PATIENTS (65)

\begin{tabular}{|c|c|c|c|c|c|c|c|}
\hline \multirow{2}{*}{$\begin{array}{c}\text { Follow- } \\
\text { up } \\
\text { (in } \\
\text { Years) }\end{array}$} & \multirow{2}{*}{$\begin{array}{l}\text { Classi- } \\
\text { fication }\end{array}$} & \multirow{2}{*}{$\begin{array}{l}\text { Satis- } \\
\text { factory }\end{array}$} & \multirow{2}{*}{\begin{tabular}{|} 
Satisfactory \\
after \\
Further \\
Operation
\end{tabular}} & \multirow{2}{*}{$\begin{array}{l}\text { Unsatis- } \\
\text { factory }\end{array}$} & \multicolumn{2}{|c|}{ Died } & \multirow[b]{2}{*}{ Total } \\
\hline & & & & & $\begin{array}{l}\text { Tuber- } \\
\text { culosis }\end{array}$ & $\begin{array}{l}\text { Other } \\
\text { Cause }\end{array}$ & \\
\hline \multirow[t]{3}{*}{$5+$} & Adv. & 25 & 5 & - & - & - & 30 \\
\hline & Inter. & 3 & - & - & 一 & - & 3 \\
\hline & Early & $\begin{array}{r}3 \\
10\end{array}$ & -1 & $\overline{1}$ & E & E & $\begin{array}{r}3 \\
12\end{array}$ \\
\hline \multirow[t]{2}{*}{$4-5$} & Adv. & $\begin{array}{r}10 \\
3\end{array}$ & $\begin{array}{l}1 \\
1\end{array}$ & 1 & E & - & $\begin{array}{r}12 \\
4\end{array}$ \\
\hline & Early & 2 & - & - & - & - & 2 \\
\hline \multirow[t]{3}{*}{$3-4$} & Adv. & $\overline{7}$ & - & - & 1 & 2 & 10 \\
\hline & Inter. & -1 & - & - & - & - & $\overline{1}$ \\
\hline & Early & 1 & - & - & - & - & 1 \\
\hline \multicolumn{2}{|c|}{ Totals } & 54 & 7 & 1 & 1 & 2 & 65 \\
\hline
\end{tabular}

One patient was omitted from Tables IV and V because death followed the operation. This case was a surgical tragedy: the clinical problem was straightforward and no complications were anticipated.

Of the 70 patients who underwent plombages, shown in Table V, 62 are apparently satisfactory without evidence of space infection. In two the balls were removed and a resection performed for unclosed cavities, five were converted to a thoracoplasty because of space infection. One died of

TABLE V

PRESENT CONDITION OF E.P. PLOMBAGE (70)

\begin{tabular}{|c|c|c|c|c|c|}
\hline $\begin{array}{l}\text { Follow-up } \\
\text { (in Years) }\end{array}$ & $\begin{array}{l}\text { Classi- } \\
\text { fication }\end{array}$ & $\begin{array}{l}\text { Satis- } \\
\text { factory }\end{array}$ & \begin{tabular}{|} 
Satisfactory \\
after \\
Further \\
Operation
\end{tabular} & $\begin{array}{l}\text { Unsatis- } \\
\text { factory }\end{array}$ & Total \\
\hline $5+$ & $\begin{array}{l}\text { Adv. } \\
\text { Inter. } \\
\text { Early }\end{array}$ & $\begin{array}{r}28 \\
3 \\
3\end{array}$ & 5 & - & 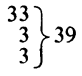 \\
\hline $4-5$ & $\begin{array}{l}\text { Adv. } \\
\text { Inter. } \\
\text { Early }\end{array}$ & $\begin{array}{r}12 \\
3 \\
2\end{array}$ & $\begin{array}{r}1 \\
1 \\
-\end{array}$ & E & $\left.\begin{array}{r}13 \\
4 \\
2\end{array}\right\} 19$ \\
\hline $3-4$ & $\begin{array}{l}\text { Adv. } \\
\text { Inter. } \\
\text { Early }\end{array}$ & $\frac{10}{1}$ & - & $\frac{1}{-}$ & $\left.\frac{11}{1}\right\} 12$ \\
\hline \multicolumn{2}{|c|}{ Totals } & 62 & 7 & 1 & 70 \\
\hline
\end{tabular}

pulmonary tuberculosis and one of the spaces was infected. In addition there was one patient in whom, following the unrecognized onset of pernicious anaemia, needling of the space produced pus with degenerate cells. No organisms could be grown though every specimen was cultured. After a few aspirations with instillation of streptomycin the fluid became serous and finally none could be obtained. The patient is well three years after this episode.

The unsatisfactory cases are shown in detail in Table VI.

TABLE VI

DETAILS OF UNSUCCESSFUL E.P. PLOMBAGE (8)

\begin{tabular}{|c|c|c|c|c|c|c|c|}
\hline \multicolumn{2}{|c|}{ Case } & \multicolumn{2}{|c|}{ Cause } & Complication & Treatment & Result & Remarks \\
\hline K.J. & . & Incomplete cav & ity closure & - & Removal of plombage & Satisfactory & Space uninfected \\
\hline W.T. & . & $\begin{array}{l}\text { Incomplete cav } \\
\text { bronchiectasi }\end{array}$ & $\begin{array}{l}\text { vity closure, } \\
\text { is }\end{array}$ & - & $\begin{array}{l}\text { Removal of plombage } \\
\text { and pneumonectomy }\end{array}$ & ," & $\begin{array}{l}\text { Primary pneumonectomy re- } \\
\text { fused by surgeon }\end{array}$ \\
\hline W.W. & . & Infection of spa & ace (T.B.) & Simple fistula & Thoracoplasty & , & Returned to work 5 weeks \\
\hline J.M. & . & , , , & , & , & , & ," & after thoracoplasty \\
\hline A.C. & . & , , , & , & , & , & ", & $\begin{array}{l}\text { Plombage on other side } \\
\text { satisfactory }\end{array}$ \\
\hline C.G. & . & , , , , & , & $\begin{array}{l}\text { Simple fistula and } \\
\text { ? space-bronchus } \\
\text { fistula. }\end{array}$ & , & $\begin{array}{l}\text { Satisfactory } \\
\text { progress }\end{array}$ & $\begin{array}{l}\text { Raised E.S.R. } 18 \text { months } \\
\text { before fistula. } \\
\text { refused to attend again }\end{array}$ \\
\hline K.H. & . & Infection of spa & $\operatorname{ace}$ & $\begin{array}{l}\text { Progressive } \\
\text { tuberculosis }\end{array}$ & 一 & Died & - \\
\hline B.S. & . & $\begin{array}{l}\text { Pus in space. } \\
\text { found }\end{array}$ & No infection & 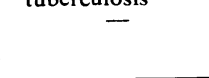 & Aspiration & Satisfactory & $\begin{array}{l}\text { Pus discovered when under } \\
\text { treatment for neglected } \\
\text { pernicious anaemia }\end{array}$ \\
\hline
\end{tabular}


Table VII shows the importance of preoperative anti-tuberculous drug treatment. In those who had inadequate drug treatment, five out of 24 patients $(20 \%)$ had become infected, and in those who had adequate drug treatment one out of $46\left(2 \frac{1}{2} \%\right)$.

TABLE VII

EFFECT OF ADEQUATE PRE-OPERATIVE ANTI-TUBER-

\begin{tabular}{|c|c|c|c|c|}
\hline Treatment & $\begin{array}{c}\text { Satis- } \\
\text { factory }\end{array}$ & $\begin{array}{l}\text { Infection } \\
\text { of Space }\end{array}$ & $\left|\begin{array}{c}\text { Pus in } \\
\text { Space } \\
\text { without } \\
\text { Infection }\end{array}\right|$ & Total \\
\hline $\begin{array}{l}\text { E.P. plombage with adequate } \\
\text { drug treatment } \\
\text { E.P. plombage without ade- } \\
\text { quate drug treatment }\end{array}$ & $\begin{array}{l}44 \\
19\end{array}$ & $\begin{array}{l}1\left(2 \frac{1}{2} \%\right) \\
5(20 \%)\end{array}$ & $\begin{array}{r}1 \\
-\end{array}$ & $\begin{array}{l}46 \\
24\end{array}$ \\
\hline Totals & 63 & 6 & 1 & 70 \\
\hline
\end{tabular}

One patient who had been adequately treated broke down recently. He had thoroughly adequate antibiotic treatment, but he was a case of very advanced bilateral fibrotic disease with cavitation on both sides, and owing to his low respiratory capacity the operation was embarked on with some diffidence. It was technically difficult with dense adhesions, but post-operatively he did not cause any undue anxiety, though the other side had to be left alone as it was feared that any operation would produce a respiratory cripple. A small fibrotic cavity persisted. He remained well for some two years, but on a routine checkup the sedimentation rate, which had approached normal, was raised. He refused to attend for further observation, and 18 months later developed a space fistula.

Nineteen patients who had no pre-operative treatment with antibiotics have remained well. One, in whom the disease was bilateral, is of interest. After four and a half years an abscess connected with the space presented under the breast and had to be dealt with by a thoracoplasty. Investigations showed that this side was the seat of less trouble than the other, but in the one that broke down no pre-operative antibiotics had been used, whereas the one that remained stable during the same period had an adequate pre-operative antibiotic course.

Among other patients undergoing a second operation, one had an unclosed cavity and a second a persistently positive sputum. At the time of the plombage the surgeon was unwilling to risk a resection, but after three months the condition was so much improved that resection was done without trouble. In both the E.P. plombage spaces were satisfactory, but probably would not have remained so in the patient with the open cavity.

My own experience confirms MacArthur's (1957) symptoms of breakdown. In all a rise in the erythrocyte sedimentation rate was an early sign. In only one of mine was there evidence of a space-bronchus fistula. Space infection occurred in one patient three and a half years after operation, in two four years after, and in three four and a half years after.

\section{Discussion}

To justify any operation it is necessary to compare it with those which are already accepted. Compared with thoracoplasty E.P. plombage has the following advantages. (1) The operation is usually less severe. (2) The collapse by variations in the strip is more selective (Luisetti and Barone, 1953). (3) There is an advantage in residual pulmonary function at least in the dangerous postoperative stage (Gaensler, Cugell, Lindgren, Verstraeten, Smith, and Strieder, 1955). (4) For young women there is a great psychological advantage in the absence of asymmetry. (5) It can be used where the disease is so advanced and widespread that thoracoplasty would be hazardous. An example of this is a man who had advanced

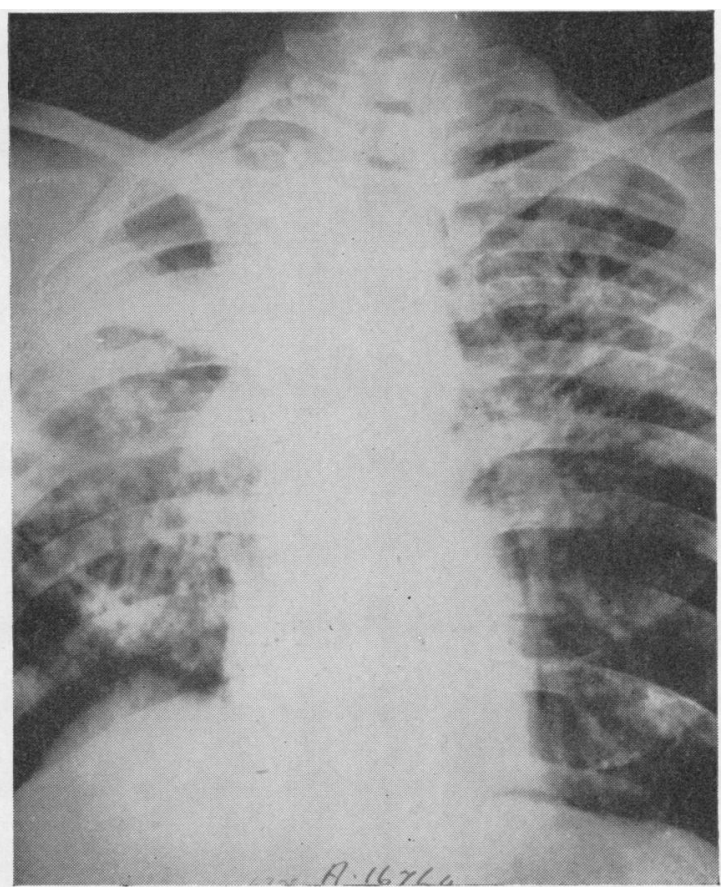

FIG. 1.-Radiograph on diagnosis on December 29, 1952. 
tuberculosis, laryngitis, and involvement of all lobes (Fig. 1). After nine months' drug treatment, multiple bilateral cavitation remained (Fig. 2). An E.P. plombage was performed without incident followed by a steady improvement with cavity closure on the other side. At the end of a further year he returned to work, and has remained well to date five years after operation (Fig. 3). This is accepted by many surgeons who condemn the principle of leaving a foreign substance in the body. (6) Even if a thoracoplasty has to be done later it is less severe than a primary thoracoplasty. Accordingly it may not be unfair to say that if E.P. plombage were free from the risk of infection it would take the place of thoracoplasty when surgical collapse was indicated.

Comparing my results with thoracoplasty from this point of view, two patients had to have the plombages dealt with subsequently by resection as the cavities had not been closed ; there is no reason to suppose that this would have been achieved by thoracoplasty, as the failure was due to the condition of the bronchi. In the one who died of tuberculosis a thoracoplasty would have been impossible, and if it had been done the cavity would not have closed. Apart from these the plombage was successful in 62 out of 67 patients.

Turning to the five patients in whom spaces became infected, only one had adequate pre-

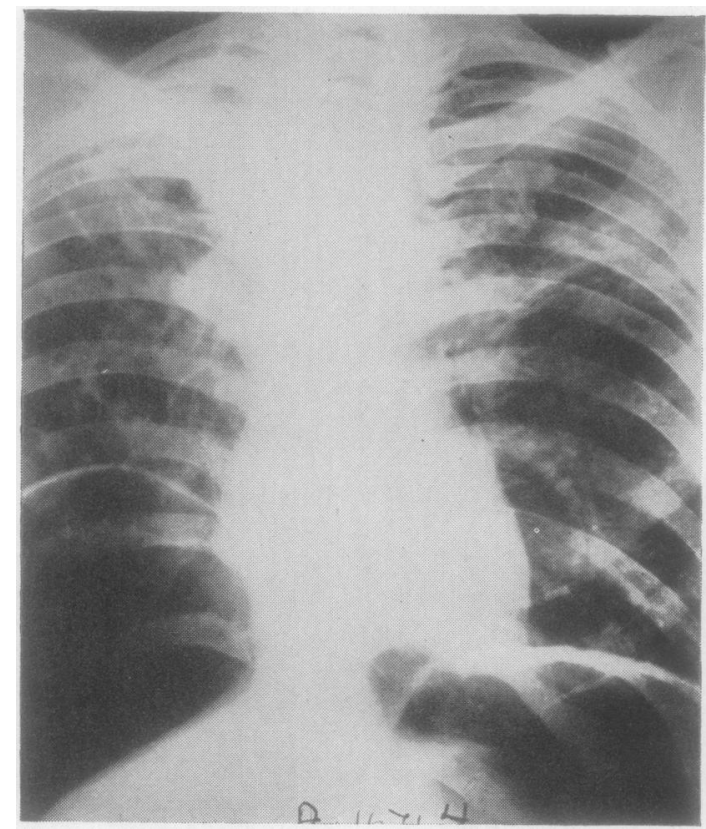

FIG. 2.-Radiograph immediately before plombage on June 20, 1953.

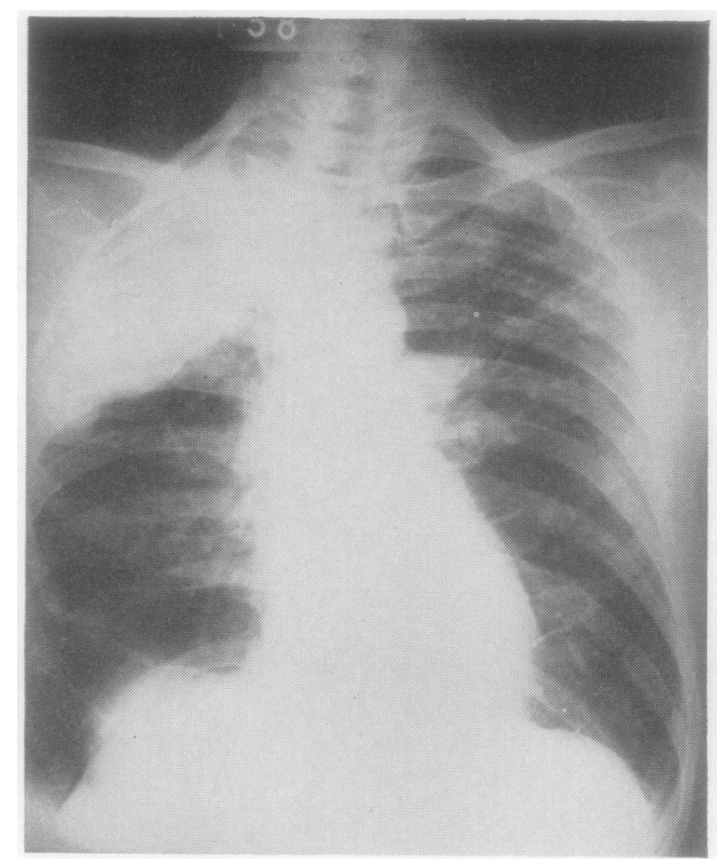

Fig. 3.-Radiograph showing condition on January 17, 1958.

operative antibiotic treatment; this patient's disease was unsuitable for thoracoplasty. According to results detailed in this paper I think it may be said that with adequate pre-operative treatment by antibiotics patients were certainly better off than if they had a thoracoplasty. Even without pre-operative therapy the final results were at least as satisfactory as the primary thoracoplasty would have been, though a second operation because of infection was necessary in five. It is, of course, realized that the condition of more patients may go wrong in the future, but the average follow-up is about five years, and nobody has been followed up for less than three.

Resections would now be preferred to plombage in a number of these patients. Nearly all of the early cases in this series were operated upon when resection was on its trial, and in some instances resection would be a preferable operation nowadays. There are, however, one or two points in favour of plombage in selected cases even where the disease is not advanced. A safe resection can be done in the case of lobectomy or small wedge resections after a period of antibiotic therapy very similar to that necessary for E.P. plombage. But where resections have to be extensive and transgress anatomical boundaries most authors consider that six months' antibiotic 
therapy is necessary in the average case. In one of the early cases quoted here the patient was four and a half months' pregnant when tuberculosis was diagnosed. After three months' antibiotic therapy the cavity was still unclosed and showed little sign of shrinking. It was felt that some surgical treatment was necessary in view of the impending parturition, and anatomically it was too early to embark on resection; accordingly a plombage was done and the pregnancy proceeded without incident. The same applies to others, not in the early category: when the patient will not persist with antibiotic therapy long enough to make resection safe, an E.P. plombage is then preferable.

There remain the advanced cases; in this series there were a number of patients in whom at least two lobes on each side were involved. All who have been classed as advanced were turned down for resection by the surgeon to whom they were submitted at the time, and I feel pretty certain in a high proportion that a refusal would be persisted in at the present time. In these any serious operative complication of resection might produce disastrous results both immediately, and subsequently where the resection has had to be larger than was anticipated by leading to respiratory crippling. In this kind of case the results of resecton performed by very experienced and skilful surgeons are different from the large series performed by many surgeons as shown in the United States Veterans' Administration (1956) report.

Where resistant organisms are present, it is probable that even the long-term risks of E.P. plombage are less than resection. At the worst the E.P. plombage may have to be followed by thoracoplasty which will not be a serious operation, whereas an infection in the course of a resection where the organisms are resistant may lead to disaster.

\section{SUMMARY}

Sixty-six patients in whom 71 plombages were performed are reported. The average period of observation was five years with a minimum of three years. Fifty-four of the patients are well without further operation; seven in addition are well after further surgery; two further patients have died of coronary thrombosis, but in these the tuberculosis was satisfactory. Out of 70 plombages, 62 were primarily effective and in a further seven the plombage was not disastrous but needed a further operation. Where infection of the space took place pre-operative drug therapy was usually inadequate. The proportion of advanced cases is high, and many of these, it is claimed, would not be suitable for other operation.

It is suggested that adequate pre-operative therapy is an important factor in avoiding space infection. If this is carried out, the hazard of space infection is low ; this risk is sufficently small to make this operation preferable to thoracoplasty ; it is preferable, when suitable, to resection in some cases where the risk of the latter is high.

\section{REFERENCES}

Cleland, W. P. (1956). J. thorac. Surg., 32, 813

Engberg, H., and Hansen, J. L. (1953). Acta tuberc. scand., 28, 45

Gaensler, E. A., Cugell, D. W., Lindgren, I., Verstraeten, J. M., Smith, S. S., and Strieder, J. W. (1955). J. thorac. Surg., 29, 163. Jackson, C. A., and McCann, J. J. (1956). Tubercle (Lond.), 37, 36. Laird, R., and Stephens, T. W. (1953). Ibid., 34, 68.

Luisetti, G. L., and Barone, L. (1953). Minerva med. (Torino), 1,684 .

MacArthur, A. M. (1957). Thorax, 12, 338.

United States Veterans' Administration (1956). Amer. Rev. Tuberc.

W3ilson, 960. N. J., Armada, O., Vindzberg, W. V., and O'Brien, W. B. (1956). J. thorac. Surg., 32, 797. 